\title{
Sanitation and Drying of Sewage Sludge on Radiant Floors Using Solar Energy and Biogas: Comparison between Different Thicknesses of Deposited Mass
}

\author{
Jéssica Cristine Gontijo ${ }^{1 *}$, Luiz Gustavo Wagner ${ }^{2}$, Mariana Espíndola de Souza ${ }^{2}$, Gustavo \\ Rafael Collere Possetti ${ }^{2}$. \\ ${ }^{1}$ Faculdade de Administração e Economia - FAE Centro Universitário, Curitiba, Paraná, Brasil; ${ }^{2}$ Companhia de \\ Saneamento do Paraná - SANEPAR, Curitiba, Paraná, Brasil.
}

\begin{abstract}
Sewage sludge is a solid waste composed of water, rich in organic matter and nutrients, but concentrator of pathogenic microorganisms. Its use as agricultural fertilizer in the state of Paraná, Brazil is common. However, it is necessary to eliminate or significantly reduce microorganisms by means of a hygiene process. This can be obtained thermally, requiring a source of energy for heat generation. In this sense, a pilot system was constructed consisting of a stainless steel radiant floor, capable of transferring heat to the sewage sludge from coils coupled in base, through which the heated water circulates. The energy comes from solar radiation and is complemented by biogas from the anaerobic sewage treatment. Aiming to investigate the system's ability to transfer heat and, consequently, to sanitize and dry the sludge, a layer of $0.10 \mathrm{~m}$ was deposited on the radiant floor, the temperature being monitored at two different heights, obtaining averages of $328.95 \mathrm{~K}\left(55.8^{\circ} \mathrm{C}\right)$ and $336.95 \mathrm{~K}\left(63.8^{\circ} \mathrm{C}\right)$, respectively. The sludge was still submitted to a drying process, where a $68.68 \%$ increase in the total solids content was verified. Finally, the energy consumption was measured where a demand of $29.22 \mathrm{Nm}^{3}$ of methane per $\mathrm{m}^{3}$ of treated sludge had been estimated.
\end{abstract}

Key words: biogas, sanitation, sewage sludge, solar energy, thermal drying.

*Author of correspondence: jessica-gontijo@hotmail.com 


\section{INTRODUCTION}

Sanitary effluents or sanitary sewers can be provided from domestic or non-domestic wastewater. In the sewage treatment process, sludge is one of the main by-products generated $^{1}$. It is a solid residue composed of water, rich in organic matter and nutrients, but concentrator of pathogenic microorganisms ${ }^{1,2}$.

The management and disposal of sewage sludge is an activity of high complexity and costly, and if poorly executed it can compromise the environmental and sanitary benefits ${ }^{1}$. Therefore, its final disposal must be sanitarily safe, environmentally favorable and economically viable, in accordance with the legislation in force in Brazil ${ }^{2}$.

Some alternatives to final disposal or use of this material are: disposal in the landfill, incineration, industrial reuse, recovery of degraded areas and agricultural recycling. However, in order to utilize this by-product in agricultural recycling, it is necessary to eliminate or significantly reduce the amount of

microorganisms present through hygiene processes.

Of the existing processes two stand out: the prolonged alkaline stabilization and the thermal path. Prolonged alkaline stabilization, a consolidated technique, regulated by the Resolution of the Council of Environment and Water Resources (SEMA) PR No. 021/2009 and widely used in the State of Paraná, has as principle the raising of the $\mathrm{pH}$ of the sludge to levels equal to or greater than 12 with the aid of alkaline chemicals, which, after ripening for 30 days, aims at inactivation or destruction of part of pathogens [2]. The amount of destroyed or inactivated pathogens classifies the sludge as Class A or Class B [3].

The thermal path, as recommended by the Resolution of the National Environmental Council (CONAMA) Number 375/06, should be performed in a heat transfer system capable of maintaining the sludge for at least $343,15 \mathrm{~K}\left(70^{\circ} \mathrm{C}\right)$ for thirty minutes [4]. Sanitation can also be achieved when the sludge is subjected to a temperature of 327.15 $\mathrm{K}\left(54^{\circ} \mathrm{C}\right)$ for a period of 2 hours [5]. However, the thermal path requires a source of energy for the generation of heat. Biogas from sewage treatment plants (STP) and solar energy are potential sources for energy generation.

Biogas is a by-product present in sewage treatment processes using anaerobic reactors. It is composed mainly of methane (CH4), a gas that has a high calorific value and can be recovered and used energetically. However, in the case of anaerobic reactors, the biogas production is directly influenced by the characteristics of the sewage that arrives to the STP and by weather conditions, resulting in a variable production during the day. Rain, for example, may completely inhibit the production of biogas [6].

This makes its use dependent on the use of a storage device or the association with another source of energy to supply the systems at a time when the biogas production is very low. In this sense, it was decided to use solar energy, by means of solar collectors of vacuum tubes, to promote a preheating of the system and to use biogas in a complementary way.

\section{OBJECTIVE}

This study aims to investigate a drying pilot thermal system and sanitation of sewage sludge, heated from the energetic use of solar radiation and biogas from domestic sewage treatment processes. As specific objectives: to analyze the temperatures in the sludge mass during the test period, the initial and final total solids content and, finally, to estimate the volume of biogas necessary to sanitize and dry the sewage sludge, in a complementary way to solar energy. 


\section{METHODS}

The pilot sewage sludge sanitation and drying system was built inside an STP with anaerobic reactors treating domestic sewage, located in the city of Curitiba-PR. The system, represented by a schematic drawing in Figure 1, consists of a prototype drying bed, of radiant floor, with an area of $1.00 \times 0.80 \mathrm{~m}$, which is capable of transferring heat to the deposited sewage sludge deposited. The whole prototype is constructed of stainless steel and equipped with coils coupled in its base, through which heated water circulates.

The water from the public supply network is sent to a reservoir of $0,200 \mathrm{~m}^{3}$ and its heating is carried out by means of its circulation in a solar collector, equipped with 15 vacuum tubes, which directs the heated water back to the thermal reservoir by the thermosyphon process.

The system is also equipped with an electric resistance, $4 \mathrm{~kW}$ power, located inside the water tank and connected to an energy meter $(0.01 \mathrm{~kW}$ resolution). The use of the resistance was intended to measure the energy needed to heat the water in addition to solar energy. In this way, the equivalent volume of biogas required by the system can be estimated.

After being heated to $90^{\circ} \mathrm{C}$ the water circulates through the radiant floor with the aid of a pump, returning to the thermal reservoir after exchanging heat in the coils in a closed circuit. The control of the operation temperature and of the electrical energy consumed by the system were performed by a control system.

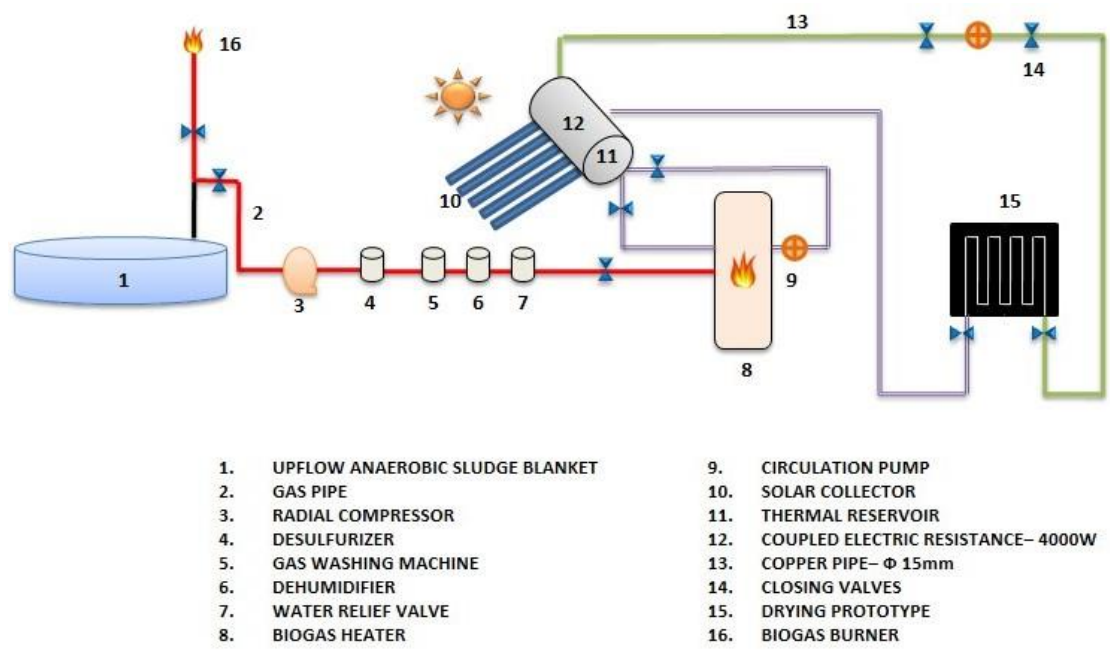

Figure 1- Schematic representation of the pilot system

Source: Authors

A sanitation and drying of sewage sludge was performed, which began on 03/31/2017 at $3: 45 \mathrm{pm}$ and lasted ten days. For this purpose, a layer of equally distributed sewage sludge of $0.1 \mathrm{~m}$ was laid. flat.

Solar energy was sufficient to heat the water to a temperature of $321.15 \mathrm{~K}\left(48.0^{\circ} \mathrm{C}\right)$. From this level the electric resistance was triggered and the energy consumed was measured.

For the first three operating days of the system, the prototype remained covered with plastic in order to maintain the moisture content in the sludge mass so as to avoid the increase of total solid content. At this stage, the temperature in the sludge mass was monitored in order to evaluate if the necessary conditions for the sludge sanitation were reached. 
To monitor the temperature in the sludge mass, 7 thermocouples were used, one of type $\mathrm{K}$ (resolution of $0.1^{\circ} \mathrm{C}$, accuracy $+/-2.2^{\circ} \mathrm{C}$ or $0.75 \%$ ) denominated $\mathrm{T} 1$ and positioned in the base of the prototype and other 6 type $\mathrm{J}$ thermocouples (resolution $0.1^{\circ} \mathrm{C}$, accuracy $+/-2.2^{\circ} \mathrm{C}$ or $0.75 \%$ ), which were named and positioned as follows: 3 thermocouples (T2, T5 and T7) positioned near the surface of the sludge mass $(0.033 \mathrm{~m}$ from the surface) and three other thermocouples (T3, T4, T6) at half the thickness of the sludge mass $(0.05 \mathrm{~m}$ from the base). They were then connected to a data acquisition module programmed to record the temperature every minute.

After the first three days of testing, the plastic cover was removed and the drying process started. Samples were collected to monitor the solids content at 0, 3,5 and 10 days.

\section{RESULTS AND DISCUSSION}

Chart 1 shows the temperature evolution in the sludge mass during the whole testing period.

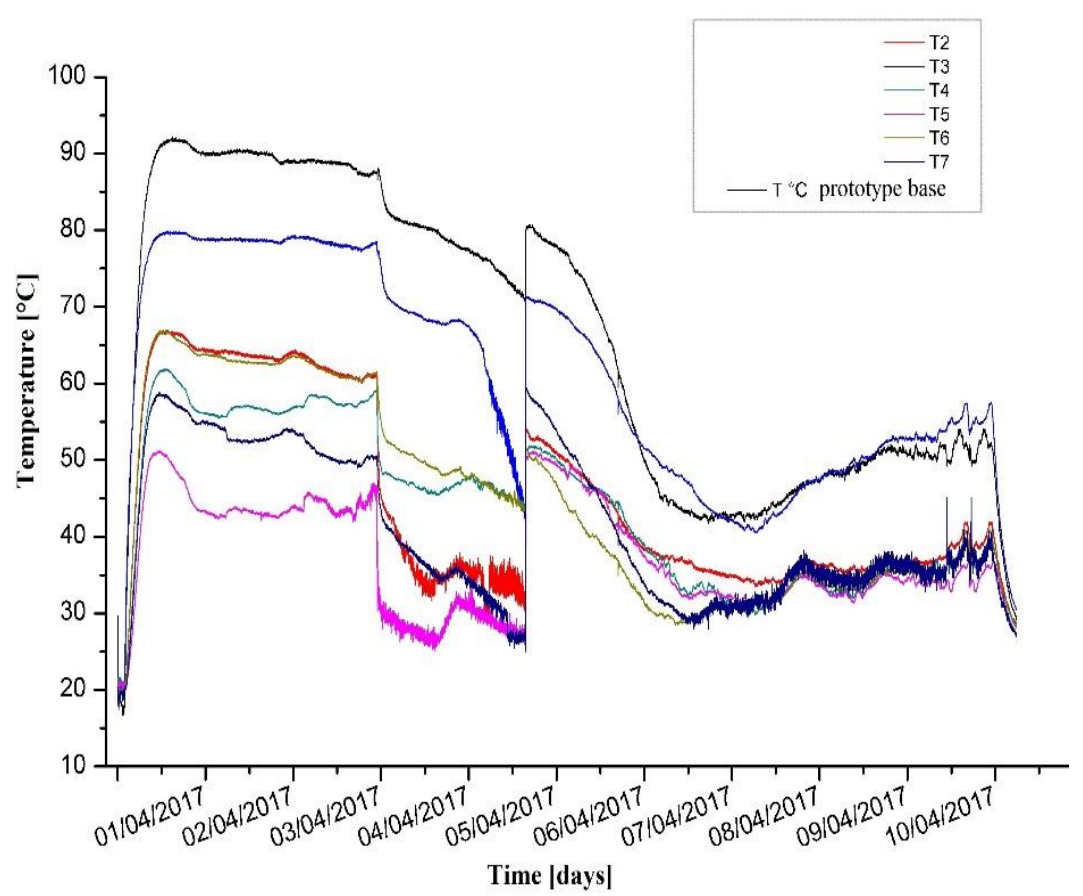

Chart 1- Evolution of the temperature in the mud mass in the ten days Source: Authors

The first three days, presented in Chart 2, are considered the period of sanitation stage. Approximately nine hours after the start of system operation, the sludge mass reached its saturation temperature. The average temperatures recorded in the sludge mass where the thermocouples were attached near the surface and in the half were respectively $328.95 \mathrm{~K}\left(55.8^{\circ} \mathrm{C}\right)$ and $336.95 \mathrm{~K}\left(63.8^{\circ} \mathrm{C}\right)$. At this stage, the maximum recorded temperature of the sludge mass in the $\mathrm{T} 3$ thermocouple was approximately $362.15 \mathrm{~K}$ $\left(79.0^{\circ} \mathrm{C}\right)$. The total solid content in the raw sewage sludge, ie at the start of the test, was $22.96 \%$. 


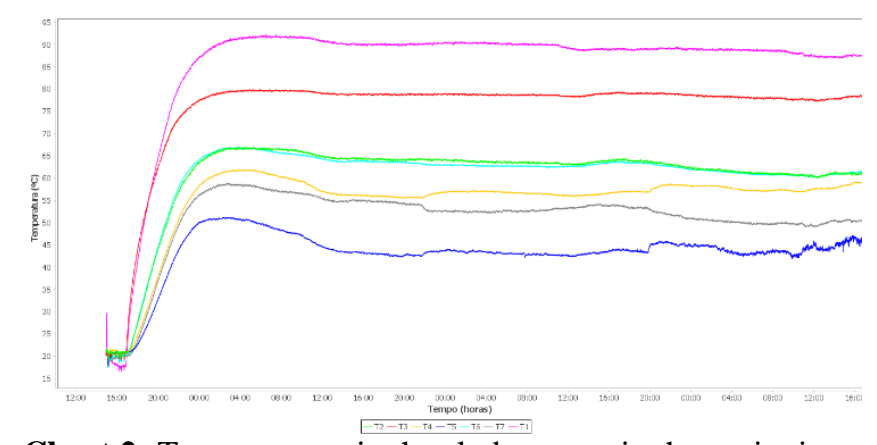

Chart 2- Temperatures in the sludge mass in the sanitation period Source: Authors

After exactly 72 hours, the plastic covers were removed, the sludge remaining for seven more days. At this time, the average temperatures recorded were $325,45 \mathrm{~K}\left(52,3{ }^{\circ} \mathrm{C}\right)$, near the surface and $\left(66,6^{\circ} \mathrm{C}\right)$, at half the thickness of the sludge mass.

From the moment the cover was removed, the temperature gradually began to decrease. In Chart 2, it is possible to observe an interference in the temperature records on the fifth day. The

thermocouples moved from their positions due to reduced sludge volume. With this, all thermocouples were repositioned.

Table 1 shows the values of the total solid content (TS) analyzed during the testing period.

Table 1 -. Total Solid Content

\begin{tabular}{cc}
\hline Day & TS (\%) \\
\hline 0 & 22,96 \\
\hline 3 & 20,79 \\
\hline 5 & 30,20 \\
\hline 10 & 91,64 \\
\hline
\end{tabular}

Source: Authors

At the end of the test, the total solid content was $91.64 \%$, an increase of $68.68 \%$ from the start of the test. Figure 2 shows the appearance of sewage sludge at the beginning and at the end of the experiment.

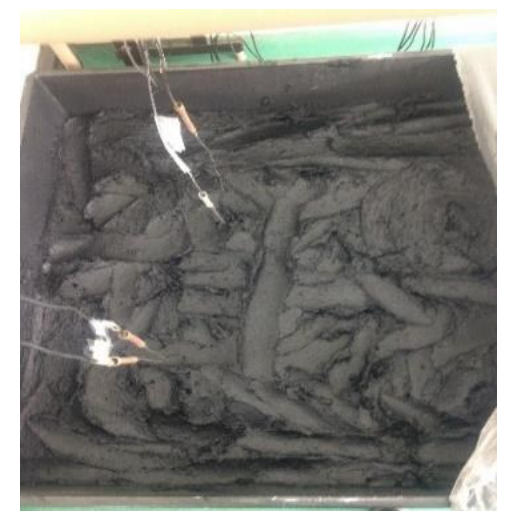

(a)

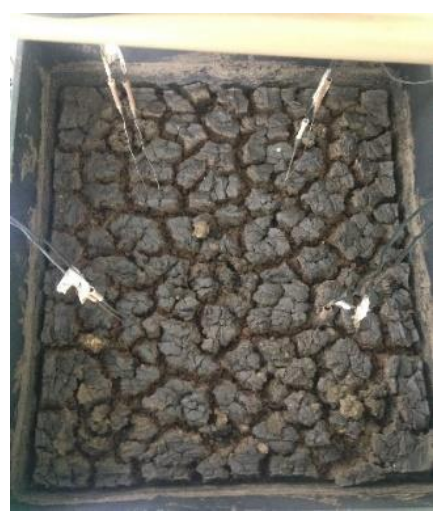

(b)

(a) appearance of the sewage sludge at the beginning and (b) at the end of the experiment Figure 2 - Aspect of the sludge before and at the end of tests Source: Authors 
The energy potential of the biogas is related to the amount of methane in its composition which, in turn, determines its calorific value [7]. Methane has a calorific power of the order of $35.9 \mathrm{MJ} / \mathrm{Nm}^{3}$, which is equivalent to $9.9 \mathrm{kWh} / \mathrm{Nm}^{3}$ [8].

The operation of the system during the ten days resulted in a total energy consumption equivalent to $403,73 \mathrm{kWh}$, or $40,37 \mathrm{kWh}$ per day. This energy was consumed by the electrical resistance that simulates the energy demanded by the biogas. Considering only the period required for sanitation (11 hours in total, 9 hours of heating and 2 hours resting), the volume of methane required was $1.87 \mathrm{Nm}^{3}$, without considering the energy losses inherent to the equipment used to burn the biogas.

Considering an $80 \%$ yield of biogas fueled water heating equipment and that the prototype used in this work treated $0.08 \mathrm{~m}^{3}$ of sludge, we can estimate a volume of approximately $29.22 \mathrm{Nm}^{3}$ of methane per $\mathrm{m}^{3}$ of sanitized sewage. This volume may vary depending on the incidence of solar radiation.

\section{CONCLUSION}

In the present work it was possible to verify that the operation of the thermal system of sanitation and drying of sewage sludge, built on a pilot scale, provided the elevation of the temperature in the sludge mass to levels sufficient for its sanitization. The average temperatures recorded, $55.8^{\circ} \mathrm{C}$ and $63.8^{\circ} \mathrm{C}$, along with the resting time of the sludge in the drying bed, were compatible with literature.

The solar energy used in conjunction with the electrical resistance coupled to the thermal reservoir, heated the water circulating in the coils coupled to $90^{\circ} \mathrm{C}$ and remained throughout the testing period. Supplementary energy consumption was $40.37 \mathrm{kWh}$ per day. Thus, the estimated volume of methane to supplement solar energy was approximately $29.22 \mathrm{Nm}^{3}$ per $\mathrm{m}^{3}$ of sanitized sewage sludge.

Regarding the final total solid content, there was an increase of $68.68 \%$ compared to the initial $22.96 \%$.

Therefore, it can be concluded that the use of solar energy and biogas from anaerobic sewage treatment are renewable sources that can be used in sanitation and sludge drying processes in hybrid thermal systems.

\section{REFERENCES}

1. Metcalf, L.; Eddy, H. Wastewater engineering: treatment and reuse . 4. ed. Revisado por George Tchobanoglous, Franklin L. Burton, H. David Stensel. McGraw - Hill, New York, 2003.

2. Andreoli, Cleverson V.; Sperling, Marcos V.; Fernandes, Fernando. Lodo de esgotos: tratamento e disposição final. 1. ed. Belo Horizonte: Departamento de Engenharia Sanitária e Ambiental da Universidade Federal de Minas Gerais; Companhia de Saneamento do Paraná, 2001.

3. Bianchini, A.; Bonfiglioli, L.; Pellegrini, M.; Saccni, C.. Sewage sludge drying process integration with a waste-to-energy power plant. Waste Management. vol 42. 159-165. 2015.

4. Pinto, Marcelo A. T et al. Higienização de Lodos. In: Andreoli, Cleverson V.; Sperling, Marcos V.; Fernandes, Fernando. Lodo de esgotos: tratamento e disposição final. Belo Horizonte, 2001. 483p.

5. Brasil - Conselho Nacional do Meio Ambiente - CONAMA. Resolução nº375, de 29 de agosto de 2006. Diário Oficial da República Federativa do Brasil. Poder Executivo, Brasília, DF, 30 ago. 2006.

6. Environment Protection Agency (1993). Biosolids Management Handbook. EPA Region VIII 40 CFR part 503 - appendix B. 
7. Ali, Idliman; Abdelkader, Lamharrar; Houssayne, Bougayr El; Mohamed, Kouhila and Khadir,Lakhal El. Solar convective drying in thin layers and modeling of municipal waste at three temperatures. Applied Thermal Engineering. vol 208. 41-47. 2016.

8. Possetti, Gustavo R. C; Jasinski, Vanessa P.; Andreoli, Cleverson V.; Bittencourt, Simone; Carneiro, Charles. Sistema térmico de higienização de lodo de esgoto movido a biogás para ETEs de médio e pequeno porte. In: Simpósio Luso-Brasileiro de Engenharia Sanitária e Ambiental, 15, 2012, Belo Horizonte, MG. Anais. Belo horizonte, 2012.

9. Andreoli, Cleverson V. Resíduos sólidos do saneamento: processamento, reciclagem e disposição final. 2011. 282 p. Rio de Janeiro.

10. Ghoneim, W.A.M.; Helal, A.A.; Abdel Wahab, M.G.. Renewable energy resources and recovery opportunities in wastewater treatment plants. 3rd international conference on renewable energies for developing countries (REDEC). 2016

11. Possetti, Gustavo R. C.; Jasinski, Vanessa P.; Mesquita, Nilton C.; Kriguel, Karina; Carneiro, Charles. Medições em tempo real do biogás produzido em reatores UASB alimentados com esgoto doméstico. In: Congresso Brasileiro de Engenharia Sanitária e Ambiental, 27, 2013, Goiânia, GO. Anais... Goiânia, 2013. 1 CD-ROM

12. Centrais Elétricas Brasileiras S.A - Procel Energia Solar para aquecimento de água no Brasil: contribuições da Eletrobrás Procel e parceiros. Luiz Menandro de Vasconcellos: Marcos Alexandre Couto Limberger (organizadores). Rio de Janeiro: Eletrobras.2012.240p.

13. Lobato, Lívia C. da Silva. Aproveitamento energético de biogás gerado em reatores UASB tratando esgoto doméstico. 2011. 184f. Dissertação (Doutorado em saneamento) - Programa de Pós-Graduação em Saneamento, Meio Ambiente e Recursos Hídricos, Universidade Federal de Minas Gerais, 2011. Disponível em: <http://www.bibliotecadigital.ufmg.br/dspace/handle/184 3/ENGD-8KYNF3 >.

14. Wagner, Luiz Gustavo. Sistema térmico de higienização e secagem de lodo de esgoto movido a energia solar e a biogás. 2015. 119p. Monografia (Especialização em Energias Renováveis) - Universidade Tecnológica Federal do Paraná. Curitiba, 2015. 